\title{
Aplikacija adaptacijskega modela Calliste Roy pri pacientu z rakom in s kronično bolečino
}

\author{
Application of Roy's adaptation model in cancer patient with chronic pain
}

\author{
Majda Čaušević, Jožica Ramšak Pajk
}

\begin{abstract}
IZVLEČEK
Ključne besede: teoretični model zdravstvene nege; Callista Roy; prilagoditev; rak; kronična bolečina

Key words: nursing models; Callista Roy; adaptation; cancer; chronic pain

Majda Čaušević, dipl. m. s., dipl. upr. org., Onkološki inštitut, Ambulanta za zdravljenje bolečine, Zaloška cesta 2, 1000 Ljubljana. Kontaktni e-naslov/ Correspondence e-mail: majda.causevic@gmail.com

viš. pred. mag. Jožica Ramšak Pajk, viš. med. ses., prof. zdr. vzg., Zdravstveni dom Ljubljana, Patronažno varstvo Crnuče, Primožičeva ul. 2, 1231 Ljubljana in Visoka šola za zdravstveno nego Jesenice, Spodnji Plavž 3, 4271 Jesenice

Uvod: Prilagajanje je ključni dejavnik za uspešno soočenje posameznika s spremembami v svojem notranjem in zunanjem okolju. Z aktivnostmi zdravstvene nege medicinske sestre pomagajo zagotoviti potrebne vire za uspešnejši proces prilagajanja. Avtorji v prispevku razpravljajo, ali bi teoretični model prilagoditve Calliste Roy ustrezal pri obravnavi in zdravstveni negi v enoti za zdravljenje bolečine.

Metode: Uporabljena je triangulacija metod pregleda literature in kvalitativne metode z raziskovalno tehniko kritičnega dogodka. Pregled literature je bil narejen v vzajemni bibliografsko-kataložni bazi COBIB.SI in Cumulative Index to Nursing and Allied Health Literature (CINAHL). Pridobljenih je bilo 165 zadetkov in uporabljenih 34 znanstvenih člankov ter 7 monografij. Kriteriji izbora so bili primarni viri Calliste Roy, dostopnost, relevantnost, kritična ponazoritev teoretičnega modela. Tehnika kritičnega dogodka v treh fazah opiše incident, ga analizira ter poda možne izide.

Rezultati: Adaptacijski model Calliste Roy je aplikativen, uporaben in v sedanji situaciji se dobro dopolnjuje s štirinajstimi temeljnimi življenjskimi aktivnostmi po Virginii Henderson. Model daje možnost ocene tako fizičnega kot psihosocialnega stanja. Najpomembnejše prepoznane intervencije medicinske sestre, $\mathrm{ki}$ pripomorejo $\mathrm{k}$ prilagoditvenemu procesu pacienta, so psihosocialna podpora, učenje in svetovanje.

Diskusija in zaključek: Prednost obravnave pacienta z rakom in bolečino po izbranem modelu zdravstvene nege je $\mathrm{v}$ možnosti ocene stanja po vseh štirih ravneh prilagajanja in $\mathrm{v}$ prikazu načrta zdravstvene nege. Pokazalo se je kot pozitivno, da medicinska sestra lahko s psihosocialno podporo in informiranjem vpliva na kakovost življenja pacienta. Pacient in družina se soočata s kronično boleznijo, načinom življenja in pomenom poznavanja ter nadzorovanja bolečine.
\end{abstract}

Članek je nastal na osnovi seminarske naloge pri predmetu Teorija in praksa zdravstvene nege magistrskega študija zdravstvene nege na Visoki šoli za zdravstveno nego Jesenice.

\section{ABSTRACT}

Introduction: Adaptation is a key factor of individual's effective coping with changes in their internal and external environment. Through their activities nurses help assure the necessary resources for a more successful process of adaptation. The article discusses the suitability of the Callista Roy's Adaptation model when tending to patients in the pain relief unit.

Methods: The research was based on a triangulation of literature review and the critical incident technique (CIT) as the qualitative research data collection method. The literature was conducted using the union bibliographic/catalogue database COBIB.SI and the Cumulative Index to Nursing and Allied Health Literature (CINAHL). A total of 165 hits were obtained yielding to 34 scientific articles and 7 monographs used for the study purposes. The selection criteria were the primary sources by Callista Roy, accessibility, relevance, and the critical analysis of the model. The method of critically reflecting on an incident (CIT ) involves three stages, namely, describing the incident and the context, analysing, and developing practice theory by considering how theory could be redeveloped as a result of the analysis.

Results: Roy's Adaptation model is one of the widely applied nursing models in nursing practice, the education and research which in the case of cancer patients naturally complements Virginia Henderson's Fourteen basic needs nursing theory. The model can be applied in the assessment of the patient's physical and psychosocial condition. Nurses can promote the adaptation process in each of the four adaptive modes by offering psychosocial support, health education and counseling.

Discussion and conclusion: The results of the current study confirm previous research related to the use of the Adaptation model of nursing in cancer patients. The model allows the assessment of the patient's condition on all four adaptation levels and planning of nursing interventions. By providing psychosocial support and information nurses can improve the quality of life and help the chronically ill patients and their families to cope with the changed daily life patterns and management of pain. 


\section{Uvod}

Široka narava prilagajanja $\mathrm{v}$ teoretičnem modelu zdravstvene nege, poznanem tudi pod imenom adaptacijski model Roy (RAM), ki ga je razvila Callista Roy, omogoča prikaz prilagajanja in razvoj intervencij zdravstvene nege, ki temelji na holističnem in integriranem pristopu. Glede na interpretacijo človeka v RAM, se človek razume kot celostno bitje, ki se nenehno spreminja $\mathrm{v}$ interakciji $\mathrm{z}$ okoljem. Razume ga kot bio-psiho-socialno bitje, ki se nahaja $\mathrm{v}$ fizičnem svetu, vendar s širšo izkušnjo in zavedanjem kozmičnega sveta (McCurry, et al., 2009; Roy, 2011).

Prilagoditveni model Calliste Roy je v uporabi že 46 let. RAM ni le prestal preizkusa časovnega testa, marveč je prispeval $\mathrm{k}$ profesionalni tranziciji $\mathrm{v}$ zdravstveni negi (Raile Alligood, 2011). Razvoj številnih teorij srednjega obsega $\mathrm{v}$ zdravstveni negi, ki je bil izrazit v zadnjih 25 letih, temelji na RAM (Roy, 2011). RAM zagotavlja smernice za prakso zdravstvene nege, izobraževanje in raziskovanje. Obsežna uporaba modela po vsem svetu ter doseganje filozofskih in znanstvenih dosežkov s strani teoretikov sta prispevala znanje za prakso zdravstvene nege, ki je zasnovano ravno na tem teoretičnem modelu (Parker, 2006). Številne raziskave kažejo (Marriner-Tomey \& Raile Alligood, 2006), da se je RAM uporabljal in testiral $\mathrm{v}$ zdravstveni negi pri različnih skupinah pacientov (starejši pacienti, pacienti s kroničnimi boleznimi, pacienti z rakom, mladostniki, novorojenci).

Ob pregledu literature lahko najdemo nekaj raziskav, kjer so teoretični model preizkusili v praksi. Yeh (2002) je preizkusila RAM na vzorcu 116 tajvanskih dečkov in deklic, obolelih za rakom. Testirala je dve trditvi Royeve. Prva trditev je, da okoljski dejavniki (resnost bolezni, starost, spol, razumevanje bolezni in komunikacija $\mathrm{z}$ drugimi) vplivajo na bio-psihosocialne odzive ( $\mathrm{z}$ zdravjem povezana kakovost življenja). Druga trditev je, da so štirje prilagoditveni načini med seboj povezani. $Z$ uporabo modeliranja strukturne enačbe je raziskovalka odkrila, da resnost bolezni zagotavlja popolno ujemanje s fazo bolezni, laboratorijskimi vrednostmi in skupnim številom hospitalizacij. Čeprav ni popolnoma jasno, kako so bili fokalni in kontekstualni dražljaji določeni, je raziskava pokazala, da okoljski dejavniki vplivajo na bio-psihosocialne odzive otrok, obolelih za rakom. Raziskava je pokazala medsebojno povezanost fiziološke ravni, samopodobe, medsebojne odvisnosti in funkcije vlog.

Tsai in sodelavci (2003) so iz RAM izpeljali teorijo o bolečini (ovrednotena kot srednje močna bolečina). V teoriji je kronična bolečina fokalni dražljaj, nezmožnost in socialna podpora sta kontekstualna dražljaja, starost in spol pa rezidualna. Zaznan vsakodnevni stres je proces spoprijemanja, depresija je spremenljivka, vidna $\mathrm{v}$ vseh štirih prilagoditvenih načinih. Večja kronična bolečina in nezmožnost sta bili povezani Z večjim vsakodnevnim stresom, večja socialna podpora pa je bila povezana $\mathrm{z}$ manjšim vsakodnevnim stresom. Te tri spremenljivke predstavljajo $35 \%$ razlike $\mathrm{v}$ vsakodnevnem stresu. Večji vsakodnevni stres je pojasnil $35 \%$ razlike $\mathrm{v}$ depresiji. $\mathrm{Z}$ raziskavo na vzorcu starejših ljudi $\mathrm{z}$ artritisom so ugotovili, da je vsakodnevni stres zelo pomemben dejavnik, ki vodi $\mathrm{v}$ depresijo.

Ashbaugh (2005) opisuje pomembnost kontinuiranega izobraževanja medicinskih sester o lajšanju akutne bolečine po operaciji. Ključni pojem za RAM pri oceni vedenja pacientov $\mathrm{v}$ procesu ocenjevanja bolečine je razumevanje procesa ocenjevanja bolečine in vpliv bolečine skozi štiri prilagoditvene ravni. Skozi izobraževanje pridobijo medicinske sestre razumevanje o tem, kako kognitivni (spoznavni) in regulativni (uravnalni) podsistem vplivata na proces prilagajanja na bolečino po operaciji. Informacije in zdravstveno vzgojni nasveti, ki jih pacient dobi s strani zdravstvenega delavca, mu pomagajo razumeti fiziologijo bolečine, spoznati razpoložljive možnosti zdravljenja in možnost sodelovanja pri odločanju. Informacije dajo pacientu in družini neko obliko zavestnega nadzora, kjer lažje razumejo neprijetne dogodke in morebiti ukrepajo, kar vpliva na njihovo dobro počutje (Maxwell, et al., 2001).

Starejši ljudje se soočajo s številnimi izzivi pri prilagajanju na staranje. $S$ tem so povezane telesne funkcije, ki poudarjajo pomen razvijanja ukrepov za spodbujanje prilagajanja staranju, kot je na primer povečanje fizične aktivnosti pri starejših. Rogers in Keller (2009) opisujeta aplikacijo RAM pri razvoju programa in ukrepov za usmerjanje promocije zdravja pri pacientih $\mathrm{z}$ rakom $\mathrm{z}$ namenom povečevanja fizične aktivnosti in kakovosti življenja. V raziskavi avtorjev (Weinert, et al., 2008) na vzorcu podeželskih žensk srednjih let $s$ kronično boleznijo so želeli potrditi dejstvo, da intervencije medicinskih sester, ki spodbujajo pozitivne psihosocialne odzive na kronično bolezen, izboljšuje kakovost življenja, spretnost $\mathrm{v}$ samoupravljanju $\mathrm{z}$ boleznijo in posledično uspešno prilagajanje kronični bolezni.

Avtorica številnih prispevkov in razprav Alison Tierney (1998) se je spraševala, ali so teoretični modeli še aktualni ali so zastareli. Modeli so orodje in odsev zdravstvene nege, ki se morajo razvijati, kajti le tako se razvija tudi znanost zdravstvene nege (Reed, 1995). Integracija modela $\mathrm{v}$ prakso zdravstvene nege bo okrepila filozofijo, profesijo kot disciplino, povezala teorijo in prakso ter širila znanje v stroki (McCurry, et al., 2009; Ramšak Pajk, 2013). Fawcett (2009) pravi, da je prvi korak pri raziskovanju ali uporabi modela $\mathrm{v}$ praksi razumevanje in natančno branje vsebine in smernic teoretičnega modela. Prispevek avtorjev Abu Shosha in Al Kalaldeh (2012) na osnovi analize 10 raziskav, pri katerih so uporabili RAM na različnih strokovnih področjih zdravstvene nege, prepozna v 8 raziskovalnih delih uporabno vrednost RAM. Prednost je v tem, da celostno obravnava posameznika in njegovo prilagajanje, pri tem pa razvija intervencije 
zdravstvene nege kot odziv na prepoznane negovalne probleme $\mathrm{z}$ namenom spodbuditi kučinkoviti prilagoditvi na vplive in odnos z okoljem.

\section{Teoretična izhodišča modela Calliste Roy}

Callista Roy je opisala teoretični model zdravstvene nege, ki temelji na konceptu prilagoditve posameznika. Po njenih besedah se prilagoditev nanaša na proces in rezultat, s čimer razmišljujoči in čuteči posamezniki samostojno ali v skupinah uporabljajo polno zavest in sprejemajo odločitve, $s$ katerimi se povežejo z ljudmi in okoljem (Roy \& Andrews, 1999; Marriner-Tomey \& Raile Alligood, 2006; Fawcett, 2009).

Znanstvene domneve za teoretični model so bile sprva zasnovane na Bertalanffyevih splošnih teorijah sistemov (Meleis, 2007). Prvo delo Royeve, ki človeka pojmuje kot sistem prilagajanja, je slonelo na Helsonovi teoriji stopnje prilagoditve (Roy, 1970; Meleis, 2007). Kasneje, pod vplivom Ralpha Turnerja, profesorja sociologije, je razvila svojo obrazložitev koncepta samopodobe in funkcije vloge. Obstajajo vzporednice med seznamom konceptov fizioloških potreb, podsistemom vedenja Dorothy E. Johnson in temeljnimi življenjskimi aktivnostmi Virginie Henderson (Meleis, 2007).

Človek, tako posameznik kot družina ali pa skupina, so obravnavani kot holistični prilagoditveni sistemi s procesom spoprijemanja, ki skrbi za vzdrževanje prilagajanja in spodbujanje sprememb posameznikov in okolja. Procesi spoprijemanja so za posameznike širše opisani $v$ regulatorskih - regulativnih (avtomatsko odzivanje) in kognatorskih - kognitivnih (zavestno odzivanje, na osnovi presoje) podsistemih, za skupine pa $\mathrm{v}$ stabilizator in inovator podsistemih (Parker, 2006). Skozi procese spoprijemanja posamezniki kot holistični prilagoditveni sistemi komunicirajo z notranjim in zunanjim okoljem, spreminjajo okolje, le-to pa spreminja njih. Določen vidik notranjega okolja je stopnja prilagoditve. To ime zajema tri možna stanja življenjskega procesa človeškega prilagoditvenega sistema: celostno, kompenzacijsko in kompromitirano (Roy \& Andrews, 1999).

Avtorica opisuje štiri kategorije za ocenjevanje vedenja, ki jih poimenuje »sistemi prilagoditve«. Prvotno so bile razvite za opisovanje oseb kot posameznikov, kasneje pa so jih razširili na skupine. To so fiziološke potrebe, samopodoba, funkcija vloge in medsebojna odvisnost (Roy \& Andrews, 1999). Osrednje prepričanje RAM-a je, da prilagoditveni odzivi podpirajo zdravje, ki je definirano kot stanje, ter proces biti in postati integriran in celosten (MarrinerTomey \& Raile Alligood, 2006; Fawcett, 2009).

$\mathrm{V}$ nadaljevanju so opisani štirje koncepti človek, zdravje, okolje in zdravstvena nega, kot jih interpretira RAM. Glede na teorijo Roy je človek bio-psiho-socialno bitje, prilagoditveni sistem in človeško bitje - v nenehnem stiku s spreminjajočim se okoljem; zato se posameznik nenehno spreminja in se poskuša prilagoditi. Po besedah Roy so ljudje holistični, prilagoditveni sistemi. Kot prilagoditveni sistem je človeški sistem opisan kot celota $\mathrm{z}$ deli, ki namensko funkcionirajo kot celota. Človeški sistemi vključujejo ljudi kot posameznike ali v skupinah, ki zajemajo družine, organizacije, skupnosti in družbo kot celoto. Roy (Roy \& Andrews, 1999) je osebo definirala kot glavno središče zdravstvene nege, prejemnika zdravstvene nege, živ, kompleksen, prilagoditveni sistem $\mathrm{z}$ notranjimi procesi (kognator in regulator), ki skrbijo za vzdrževanje prilagoditve $\mathrm{v}$ štirih prilagoditvenih načinih (fiziološka potreba, koncept samopodobe, funkcija vloge in neodvisnost). Ko se posameznik ne prilagaja pozitivno, se izkaže potreba po zdravstveni negi; vendar pa, ko posameznik doseže pozitivno vedenje, potrebe po zdravstveni negi nima več (Parker, 2006).

V svojih zgodnejših delih je Roy $z$ dravje opazovala pri kontinuumu zdravje - bolezen od skrajno slabega zdravja do visoke stopnje dobrega zdravja (Brower \& Baker, 1976). V zadnjih delih je osrednjo pozornost namenila bolj zdravju kot procesu, $\mathrm{v}$ katerem lahko zdravje in bolezen soobstajata (Roy, 2002). Kadar so mehanizmi za spoprijemanje s spremenjenimi okoliščinami neuspešni, nastopi bolezen. Zdravje izhaja iz človekovega nenehnega prilagajanja. Ko se ljudje prilagodijo na dražljaje, se lahko odzovejo na druge dražljaje. Roy opisuje, da je zdrav posameznik tisti, katerega integriteta je bila zaščitena kot rezultat njegove sposobnosti prilagoditve. Bolezen je torej stanje ogrožene integritete, ki nastane kot rezultat nesposobnosti prilagoditve ali slabih odzivov na dražljaje (Hajdinjak \& Meglič, 2012).

Po besedah Roy okolje vpliva na posameznika kot prilagoditveni sistem, ki zajema tako notranje kot tudi zunanje dejavnike. Ti dejavniki so lahko majhni ali veliki, negativni ali pozitivni. Kakor koli, okoljska sprememba zahteva veliko energije za prilagoditev situaciji. Faktorji v okolju, ki vplivajo na posameznika, so kategorizirani kot fokalni, kontekstualni in rezidualni dražljaji (Marriner-Tomey \& Raile Alligood, 2006). Notranje in zunanje okolje sestavljajo vsi pojavi, ki obkrožajo človeški sistem prilagajanja in vplivajo na njihov razvoj in vedenje. Posamezniki so v nenehnem stiku $\mathrm{z}$ okoljem in izmenjujejo informacije, snov in energijo; torej posamezniki vplivajo na okolje, le-to pa vpliva na njih. Okolje je vir dražljajev, ki ogrožajo ali spodbujajo posameznikov obstoj. Za preživetje se mora človeški sistem prilagajanja odzvati pozitivno na dražljaj iz okolja. Prilagoditev spodbuja preživetje, rast, razmnoževanje, spoprijemanje in spremembo posameznikov in okolja. Roy definira zdravje kot stanje nastajanja integriranega in celostnega človeškega bitja (Marriner-Tomey \& Raile Alligood, 2006).

Roy definira zdravstveno nego kot znanost in prakso, ki razširi sposobnost prilagajanja in spodbuja spremembo posameznika in okolja. 
Dejavnost zdravstvene nege enači $\mathrm{z}$ oceno vedenja in dražljajev, ki vplivajo na prilagoditev (Fawcett, 2009). Presoja zdravstvene nege temelji na oceni, aktivnosti pa so načrtovane za nadzor dražljajev. Cilj zdravstvene nege je po mnenju Roy »spodbujanje prilagajanja posameznikov in skupin $\mathrm{v}$ vsakem od štirih prilagoditvenih načinov in tako prispeva $\mathrm{k}$ zdravju, kakovosti življenja ter dostojni smrti« (McCurry, et al., 2009). Zdravstvena nega ima posebno vlogo kot posrednik $\mathrm{v}$ prilagajanju $\mathrm{Z}$ ocenjevanjem vedenja $\mathrm{v}$ vsakem od teh štirih prilagoditvenih načinov, dejavnikov, ki vplivajo na prilagajanje, in s posegi, ki spodbujajo sposobnost prilagajanja ter spodbujajo stik z okoljem (Roy, 1997).

\section{Namen in cilj}

Namen prispevka je predstaviti in razpravljati o možnosti, da bi bil model Calliste Roy primernejši ali se dopolnjeval pri obravnavi pacienta $\mathrm{z}$ rakom in $\mathrm{z}$ bolečino v primerjavi $\mathrm{z}$ obstoječo teorijo in štirinajstimi življenjskimi aktivnostmi Virginie Henderson. Namen je tudi kritično predstaviti in opisati teoretični model $z$ dravstvene nege Calliste Roy, izpostaviti štiri koncepte ter na osnovi kritičnega dogodka po šest stopenjskem procesu zdravstvene nege Calliste Roy podati specifično ter na dokazih podprto obravnavo $\mathrm{z}$ intervencijami in pričakovanimi izidi zdravstvene nege.

\section{Metode}

Pri izboru raziskovalnih metod smo uporabili triangulacijo. Najprej smo uporabili metodo pregleda literature, sledila je kvalitativna metoda dela $\mathrm{z}$ raziskovalno tehniko kritičnega dogodka (Schluter, et al., 2008). Za namen opisa in prikaza pojmov, povezav teorije Calliste Roy ter aplikativne vrednosti pri pacientih $\mathrm{z}$ rakom in bolečino je uporabljena deskriptivna raziskovalna metoda pregleda literature. Pregled literature je bil narejen v vzajemni bibliografsko-kataložni bazi COBIB. SI in Cumulative Index to Nursing and Allied Health Literature (CINAHL). Pregled literature je potekal od 1. 2. 2013 do 31. 3. 2013. Uporabili smo več ključnih besed v medsebojni kombinaciji, in sicer: adaptacijski model Roy in bolečina/Roy's adaptation model AND pain, adaptacijski model Roy in rak/Roy's adaptation model AND cancer ter kronična bolečina raka in zdravstvena nega/cancer chronic pain AND nursing. Dobili smo skupaj 165 zadetkov, od tega je bilo uporabljenih 34 člankov in 7 monografij. Kriteriji za izbor relevantne literature so bili prosta dostopnost celotnega besedila, raziskovalni znanstveni članki, letnice kot omejitve nismo uporabili. Kriterij je bil uporabiti primarne vire teoretičarke Calliste Roy in monografije drugih znanih teoretičark za namen kritičnega prikaza teoretičnega modela. Kot izjemo smo uporabili relevantne znanstvene članke starejšega datuma avtorjev, ki so v svojih raziskavah uporabili teoretični model Calliste Roy.

\section{Opis kritičnega dogodka}

Tehnika kritičnega dogodka zajema tri faze, in sicer (a) opiše dogodek in vse vpletene, (b) analizira dogodek in utemelji vse odločitve ter (c) analizira intervencije zdravstvene nege s pričakovanimi izidi. V prvi fazi predstavimo kritičen dogodek, ki je opisan po spominu in je za avtorja pomemben. Dogodek je izbran priložnostno in glede na delovno okolje. $\mathrm{V}$ zadnjih dveh fazah za namen prikaza obravnave sledimo procesni metodi dela $\mathrm{v}$ šestih korakih, kot ga je v svojem teoretičnem modelu zdravstvene nege predstavila Callista Roy, in vsako fazo podkrepimo z relevantno literaturo.

$\mathrm{V}$ članku je prikazana možnost aplikacije prilagoditvenega modela na proces zdravstvene nege pri pacientu z rakom, ki ima hude bolečine. Scenarij/ incident prikazuje eno izmed pogostih situacij, ki jih srečujemo pri vsakdanjem delu v ambulanti za zdravljenje bolečine.

»Na enoto za terapijo bolečine na Onkološkem inštitutu je gospa pripeljala 65-letnega moža zaradi hudih bolečin. Gospod je imel napredujočo obliko raka. Med pogovorom $z$ zdravstvenim osebjem je gospa povedala, da ima njen možhude bolečine, motnje spanja, da je zelo utrujen in depresiven. Pacient je bil vidno prizadet. Medicinske sestre in zdravnica so opazile, da pacient in njegova žena nista bila dobro seznanjena $s$ tem, kako lajšati bolečine ter kje poiskati pomoč v takem primeru. Opazili so, da je pacientova žena zelo utrujena in žalostna. Zdelo se je, da ima občutek nemoči.

Medicinska sestra je preverila pacientove vitalne funkcije. Pacient je izpolnil vprašalnik o bolečini in po pregledu pri zdravnici prejel recepte za zdravila in navodila, kako jemati zdravila. Dobila sta telefonsko številko ambulante za terapijo bolečine in informacije o tem, kako in kdaj poiskati pomoč.

Zdravnica je odredila kontrolni pregled čez en teden. Ko sta prišla na kontrolni pregled, sta povedala, da se je bolečina zmanjšala, pacient je bolje spal.

Še vedno je bil potrt, njegova žena je bila še vedno zelo žalostna in utrujena. Medicinske sestre so predvidevale, da se par verjetno premalo ali sploh ne pogovarja o bolezni in njenih posledicah."

\section{Rezultati}

RAM obravnava proces zdravstvene nege, ki ga Roy imenuje proces reševanja problemov. To dosežemo $s$ pomočjo šeststopenjskega procesa zdravstvene nege: ocena vedenja, ocena dejavnikov vplivanja, negovalne diagnoze, določitev ciljev, intervencija in evalvacija (Masters, 2012). Negovalne intervencije so osredotočene na obvladovanje okoljskih dejavnikov s »spreminjanjem, naraščanjem, zmanjšanjem, odstranjevanjem ali ohranjanjem le-teh« (Roy, 1997).

Adaptacijski model je pristop $\mathrm{k}$ reševanju problemov za zbiranje in ugotavljanje podatkov, 
ugotavljanje zmogljivosti in potreb posameznika po nekem prilagoditvenem sistemu; je izbira in izvajanje pristopov za zdravstveno nego in ocenjevanje izida intervencij zdravstvene nege (Fawcett, 2009). Ocenjevanje je sistematično in omogoča organiziran pregled pacientovih potreb (Meleis, 2007). Proces poteka $\mathrm{v}$ naslednjih korakih :

\section{Ocena vedenja}

Ocena pacientovega vedenja je ocena vedenja osebe na vseh štirih ravneh: v fiziološkem sistemu, sistemu samopodobe, sistemu funkcije vlog in sistemu medsebojne odvisnosti (Marriner-Tomey \& Raile Alligood, 2006; McCurry, et al., 2009). Fiziološkofizični prilagoditveni način se ukvarja $\mathrm{z}$ načinom človekove interakcije $\mathrm{z}$ okoljem skozi fiziološke procese, da bi zadostili potrebam (govorimo o petih potrebah, ki jih je treba zadovoljevati) po oksigenaciji, hrani, izločanju, gibanju in počitku ter varnosti. Prilagoditveni način identitete samopodobe se ukvarja s potrebo po spoznavanju, kdo človek je in kako se obnašati v družbi. Roy definira posameznikovo samopodobo kot »zmes prepričanj ali čustev, ki jih posameznik ima o sebi ob določenem času" (Roy \& Andrews, 1999). Posameznikova samopodoba je sestavljena iz fizičnega jaza (telesni občutki in telesna podoba) in osebnega jaza (osebna doslednost, osebni ideal in moralno-etično-duhovni jaz). Prilagoditveni način funkcije vlog opisuje primarne, sekundarne in terciarne vloge, ki jih posameznik igra v družbi. Vloga opisuje pričakovanja o tem, kako se oseba obnaša do druge osebe. Prilagoditveni način medsebojne odvisnosti opisuje interakcijo med ljudmi v družbi. Glavna naloga prilagoditvenega načina medsebojne odvisnosti je, da ljudje dajejo in sprejemajo ljubezen, spoštovanje in se cenijo. Najpomembnejši deli sistema medsebojne odvisnosti so posameznikovi bližnji (zakonec, otrok, prijatelj ali bog) in njegov socialni podporni sistem. Pomembno je vedeti, kakšna je njegova soodvisnost v odnosih. Biti ljubljen in sprejet ter imeti ob sebi druge ljudi, so pomembni viri pozitivnih čustev (Pinquart \& Frohlich, 2009). Cilj štirih prilagoditvenih načinov medsebojne odvisnosti je doseči fiziološko, psihološko in socialno celovitost (Marriner-Tomey \& Raile Alligood, 2006). Študija (Skjutar \& Müllersdorf, 2010) pri pacientih s kronično bolečino navaja, da so udeleženci izrazili potrebo po preoblikovanju samopodobe kot tudi potrebo po intervencijah, ki spodbujajo družabno življenje in usmerjajo paciente $\mathrm{k}$ iskanju lastnih virov moči.

Medicinska sestra opazuje pacienta, zbira informacije in ugotavlja, kakšna je njegova možnost prilagoditvenih načinov. Izpostavimo probleme, glede na njihovo prilagoditev. Oceni, da ima pacient hudo bolečino, ima moten spanec, je utrujen in depresiven. $\mathrm{Na}$ podlagi zbranih informacij ugotovi, da lahko pacienta uvrsti v fiziološko raven in raven medsebojne odvisnosti.

\section{Ocena dražljajev}

Drugi korak procesa zdravstvene nege vključuje identifikacijo notranjih in zunanjih dejavnikov, ki vplivajo na človekovo prilagoditveno vedenje. RAM opisuje tri tipe okoljskih dražljajev. Fokalni dražljaji so tisti, s katerim se posameznik najprej sooči in zahteva največ pozornosti in energije za prilagoditev. Kontekstualni so vsi ostali dražljaji, ki so prisotni v situaciji in pozitivno ali negativno prispevajo $\mathrm{k}$ moči fokalnega dražljaja. Rezidualni stimuli vplivajo na fokalne dražljaje, vendar pa njihovi učinki niso znani takoj. Ti trije tipi dražljajev skupaj tvorijo stopnjo prilagoditve. Prilagoditev se zgodi, ko se posameznik pozitivno odzove na okoljske spremembe. Ta prilagoditveni odziv spodbuja integriteto posameznika, ki vodi do zdravja v okviru kontinuuma zdravje - bolezen (Baldacchino, et al., 2013). Neučinkoviti odzivi na dražljaje predstavljajo oviro v integriteti posameznika (Roy, 1970, 1971).

Vloga medicinske sestre je prepoznati dražljaje in planirati intervencije, ki bodo ojačali ali spremenili prilagoditveni proces pri posamezniku (McCurry, et al., 2009). Roy želi, da medicinska sestra pozna človeka celovito (Fawcett, 2009).

Medicinska sestra oceni dejavnike za vedenja, ki jih razvrsti kot fokalne, kontekstualne ali rezidualne dražljaje. Fokalni dražljaji so v tem primeru rak, huda bolečina in pomanjkanje motivacije. Kontekstualni dražljaji so moteno spanje, izčrpanost ter pomanjkljive informacije o bolezni in zdravljenju. Kot rezidualni dražljaj bi $\mathrm{v}$ tem primeru lahko izpostavili socialno izoliranost. Nicholson (2009) opredeljuje socialno izolacijo kot sindrom ali asociacijo več prepoznavnih značilnosti, kar je podobno opredelitvi ostalih sindromov, kot so na primer metabolni sindromi. V nekaterih okoljih doživljajo rak kot stigmo. Stigmatizacija oseb, ki se štejejo za drugačne ali manjvredne, je globalni fenomen in se pojavlja $\mathrm{v}$ vseh kulturah (Phillips, 2011).

\section{Določitev negovalnih diagnoz}

$\mathrm{V}$ tem koraku medicinska sestra določi negovalno diagnozo o prilagoditvenem stanju osebe (MarrinerTomey \& Raile Alligood, 2006). Negovalna diagnoza je povezana s fiziološko ravnjo, saj ima pacient hude bolečine, zato mora medicinska sestra negovalno diagnozo osredotočiti na obvladovanje bolečine. Kronična bolečina je kompleksna. Ravno zaradi tega je težko razumeti potrebe pacienta, povezanih $\mathrm{z}$ bolečino (Skjutar \& Müllersdorf, 2010). Negovalna diagnoza je povezana tudi z ravnjo medsebojne odvisnosti, saj pacient kaže pomanjkanje motivacije, depresijo, žalost in posledično povečano izčrpanost, moteno spanje in utrujenost. Büssing in sodelavci (2010) ugotavljajo, da večina pacientov $s$ kronično boleznijo ni zmožna samostojno upravljati lajšanja bolečine. Pacienti se 
težko distancirajo od negativnih občutkov, povezanih z bolečino, da bi lahko našli ustrezne načine prilagoditve na dolgotrajen potek bolezni. Avtorji menijo, da k temu pripomorejo vedenjsko kognitivne spremembe pri pacientu, $\mathrm{v}$ smislu spremenjenega pogleda na življenje, zavesti glede zdravja, fizične sposobnosti in pozitivnega razmišljanja.

\section{Določitev ciljev-načrtovanje}

Medicinska sestra zastavi cilje za spodbujanje prilagajanj. Z določanjem ciljev medicinska sestra jasno opredeli, kakšne spremembe pri pacientovem vedenju želi doseči s pomočjo intervencij zdravstvene nege (Roy \& Andrews, 1999). Določanje ciljev poteka $\mathrm{v}$ medsebojnem sodelovanju med medicinsko sestro in pacientom, kadar je to možno (Marriner-Tomey \& Raile Alligood, 2006). Medicinska sestra določi kratkoročne in dolgoročne cilje. V kratkoročnih ciljih je opredeljeno pričakovano pacientovo vedenje ob prilagoditvi fokalnih, rezidualnih in kontekstualnih dražljajev. Prav tako je v teh ciljih opredeljeno vedenje pacienta $\mathrm{z}$ vidika regulatornih in kognitivnih sposobnosti obvladovanja dražljajev (Hajdinjak \& Meglič, 2012). Kot kratkoročne cilje za pacienta lahko opredelimo izboljšanje načinov za obvladovanje bolečine, izboljšanje spanja in zmanjšanje utrujenosti. Dolgoročni cilji odražajo razrešitev problemov pacientov pri prilagajanju, oziroma njihovo omilitev $\mathrm{v}$ največji možni meri (Fawcett, 2009). Za dolgoročni cilj pri pacientu lahko opredelimo pomoč medicinske sestre pacientu in njegovi ženi zgraditi socialno mrežo (npr. Društvo pacientov obolelih z rakom, Ambulanta za zdravljenje bolečine). Avtorji (Büssing, et al., 2010) poudarjajo, da je pacientovo prilagajanje na kronično bolečino dolgotrajen proces, ki vključuje tako kognitivne, vedenjske kot čustvene odzive.

\section{Intervencije}

Cilj intervencij zdravstvene nege je spodbujati prilagoditvene odzive posameznika, družine ali skupnosti (Fawcett, 2009). Ko se posameznik sooči z dražljaji iz okolja, se aktivirajo štirje med seboj povezani prilagoditveni načini vedenja, ki odražajo sposobnost prilagoditve in odziva posameznika (Bakan \& Akyol, 2008). Medicinska sestra izpelje intervencije z namenom obvladovanja dražljajev za spodbujanje prilagajanja (Marriner-Tomey \& Raile Alligood, 2006). Bolj ko se posameznik zaveda svojega stanja, zna prepoznati in obvladati bolečino ter je duhovno pomirjen, tem lažje sprejema diagnozo rak in življenje z bolečino (Dobratz, 2005). Skjutar in Müllersdorf (2010) v raziskavi ugotavljata potrebo po intervencijah na področju skrbi za socialne odnose, uživanju življenja in spodbujanju pacientov, da sami razvijejo načine za motivacijo.
Medicinska sestra bo za dosego ciljev priskrbela svetovanje o obvladovanju bolečine (dala recepte in navodila za jemanje zdravil), spanju in utrujenosti. $\mathrm{V}$ naslednji fazi, ko se bo bolečina zmanjšala, bo medicinska sestra izpeljala intervencije v sodelovanju $s$ pacientom in pacientovimi svojci ter ostalimi udeleženci v socialni mreži (npr. patronažna služba, osebni zdravnik, hospic, Društvo onkoloških bolnikov). Ramini in sodelavci (2008) so v svoji raziskavi ugotovili, da druženje v skupini s podobnimi problemi in širjenje socialne mreže pomembno vpliva na prilagajanje in sprejemanje bolečine.

\section{Evalvacija}

$\mathrm{Za}$ uspešno spoprijemanje $\mathrm{s}$ kronično boleznijo, posamezniki poskušajo doseči ravnovesje med okoljskimi dejavniki in bio-psiho-socialnimi dejavniki ter duhovno dimenzijo. Če tega ravnotežja ni mogoče doseči in ohraniti, se posameznik ni sposoben spopasti $\mathrm{s}$ situacijo in se pokaže primanjkljaj v prilagajanju (Roy, 2002; Baldacchino, et al., 2013). Avtorji (Weinert, et al., 2008) navajajo, da posameznik s kronično boleznijo, ki se je sposoben prilagoditi trenutnemu zdravstvenemu stanju, lažje obvladuje situacijo in ima bolj kakovostno življenja.

V tem koraku procesa zdravstvene nege medicinska sestra oceni, ali so bili prilagoditveni cilji doseženi (Marriner-Tomey \& Raile Alligood, 2006). Pričakovani rezultati se odražajo $\mathrm{v}$ spremenjenem ali prilagojenem vedenju pacienta v spremenjeni situaciji. Vrednoti se tudi, ali so bile intervencije zdravstvene nege učinkovite ter učinkovitost zdravstvene nege (Hajdinjak \& Meglič, 2012). S pomočjo evalvacije bo medicinska sestra ugotovila pacientovo stanje glede bolečine, razpoloženja, spanja, izčrpanosti in socializacije. Tudi socialna izoliranost je merljiva. Nicholson (2009) meni, da je socialna izoliranost sindrom ali vedenje, ki ga lahko medicinska sestra ovrednoti. Če je rezultat še vedno neprilagojeno vedenje, je treba izvesti dodatno evalvacijo dejanj zdravstvene nege $\mathrm{z}$ razmislekom o drugačnem pristopu. Medicinska sestra ima $\mathrm{v}$ procesu obravnave zelo pomembno nalogo tako glede spremljanja doseženih ciljev kot v vrednotenju uspešnosti koordinacije $\mathrm{z}$ drugimi službami in združenji. Podobno navaja avtorica Chapman (2012) da je vloga medicinske sestre $\mathrm{v}$ obravnavi bolečine $\mathrm{v}$ okviru interdisciplinarnega tima ključna.

\section{Diskusija}

Pri pregledu literature lahko vidimo, da je teoretični model RAM globoko zasidran $\mathrm{v}$ praksi zdravstvene nege, kar $\mathrm{v}$ določeni meri prispeva $\mathrm{k}$ njegovemu neprekinjenemu uspehu (Roy, 2002). Ostaja eden najpogosteje uporabljenih konceptualnih okvirov za poučevanje zdravstvene nege tako na državni kot mednarodni ravni (Fawcett, 2005). Edinstven vidik 
zdravstvene nege je razumevanje izkušenj pacientov za načrtovanje in zagotavljanje kakovostne zdravstvene nege (Phillips, 2011). Cilj zdravstvene nege in teoretičnega modela je človekova prilagoditev na štirih prilagoditvenih ravneh v primeru zdravja in bolezni. Ko posameznik ne zmore več samostojne prilagoditve na spremembe iz okolja, potrebuje pomoč, ki mu jo kakovostno lahko zagotovi medicinska sestra, vendar le, če pozna njegove potrebe (McCurry, et al., 2009). Model zdravstvene nege opiše medicinsko sestro kot osebo, ki ima strategijo za integracijo potreb osebe $\mathrm{v}$ celoti, kajti njena pozornost je usmerjena $\mathrm{v}$ to, da upošteva pacienta kot celovito osebnost (Frederickson, 2011). Celosten pristop z obravnavo pacienta in družine je bil tudi v našem primeru RAM koristno ogrodje pri delu medicinske sestre. Povezovanje teorije s prakso zdravstvene nege služi kot vodilo za doseganje ciljev zdravstvene nege in spodbujanje zdravja (McCurry, et al., 2009).

Teoretični model, ki je bil uporabljen na omenjenem primeru v praksi, je model V. Henderson, ki je nekako najbolj uporabljen model $\mathrm{v}$ našem prostoru in pri katerem medicinska sestra pomaga pacientu pri življenjskih aktivnostih za ohranjanje zdravja, vrnitvi zdravja in pri mirni smrti. Pozitivno pri obravnavi je, da so medicinske sestre poskrbele za temeljne življenjske potrebe. To vključuje preverjanje njegovih vitalnih funkcij in podajanje informacij o lajšanju bolečine $\mathrm{z}$ zdravili ter boljšemu spanju in počitku. V RAM zdravstvena nega deluje tako, da bi okrepila interakcijo osebe $\mathrm{z}$ okoljem, $\mathrm{z}$ namenom spodbujati prilagoditev. Boljši scenarij za pacienta iz prakse bi bil, da se ga obravnava $s$ štirimi prilagoditvenimi načini. Za obravnavo opisanega pacienta lahko potrdimo, da je RAM v več pogledih boljši od modela V. Henderson. V teoretičnem modelu V. Henderson so v ospredju fiziološke potrebe. Kljub temu da so že predstavljene tudi psihološke in socialne potrebe, pa $\mathrm{v}$ modelu V. Henderson ni konceptualne povezave med vsemi potrebami tako kot v RAM, kjer so potrebe predstavljene kot skupek med seboj povezanih podsistemov. V RAM je najviši cilj spodbujanje celovitega prilagajanja katerega koli od štirih prilagoditvenih načinov. Menimo, da se pacientu iz prakse ni treba prilagoditi bolečini, ampak mora bolečino obvladati. Pacienta se obravnava celostno skupaj s svojci. Glede na to, da gre za težko čustveno doživljanje bolezni pri obeh partnerjih, je treba $\mathrm{v}$ obravnavo vključiti psihosocialni vidik in dejavnike iz okolja, kar je največja aplikativna vrednost RAM. Telesno in duševno zdravje se medsebojno tesno prepletata in nenehno vplivata drug na drugega. Rak je bolezen, ki globoko poseže v življenje bolnih in njihovih svojcev. Pogostost depresije pri pacientih z rakom se po ocenah, pridobljenih v nekaterih raziskavah, giblje od 4,5 do 58 $\%$ oziroma $75 \%$ (Snoj, 2009). V našem primeru smo pri pacientu kot pri njegovi ženi zaznali znake obupa, nemoči, negativnih misli, socialno izoliranost. Pacient mora sprejeti in se prilagoditi kronični bolečini saj je doživljenjska.

Ko pacient doseže fiziološko, psihološko in duhovno okrevanje, je zelo pomembno, kaj oseba počne $\mathrm{v}$ družbi. Osnovna potreba prilagoditvenega načina obvladovanja vlog je socialna celovitost, ali, da vedo, kako se obnašati in kaj se od njih pričakuje $\mathrm{v}$ družbi. Prilagoditveni način medsebojne odvisnosti se nanaša na odnose med ljudmi. Osnovna potreba prilagoditvenega načina medsebojne odvisnosti je socialna celovitost ali dajati in prejemati ljubezen, spoštovanje in biti cenjen s strani pomembnih drugih in socialnih podpornih sistemov (Roy, 1997). Pomembno je vedeti, kakšna je njegova soodvisnost v odnosih (Pinquart \& Frohlich, 2009). V našem primeru se je komunikacija in vzpostavljanje dobrega medosebnega odnosa izkazalo za zelo pomembno. Nicholson (2009) v svojem članku razpravlja, da RAM opisuje medicinsko sestro kot osebo, ki lahko pomaga pacientu $\mathrm{v}$ procesu prilagajanja in razvoju mehanizmov spoprijemanja tudi v konceptu socialne izoliranosti. Problem RAM vidi v tem, da je težko najti posebne rešitve, $s$ katerimi bi lahko medicinska sestra pomagala starejšim pacientom pri prilagoditvi. Zato je pomembno, da je medicinska sestra sposobna prepoznati psihosocialna vprašanja, ki predstavljajo tveganje za zdravje takih pacientov.

Kljub kompleksnosti je RAM notranje skladen in ga lahko posplošimo tako $\mathrm{v}$ praksi kot $\mathrm{v}$ raziskovanju (Philips, 2011). Torej je RAM kompleksen, abstrakten in zahteven za razumevanje. Medicinska sestra mora prepoznati pacientovo dojemanje zdravstvenega problema. Model Roy zagotavlja kritično razmišljanje (Roy, 2002). Usmerjen je v prilagajanje kronične bolezni in delovanje znotraj družine. Nuamah in sodelavci (1999) so proučevali kakovost življenja 515 otrok, obolelih za rakom. Njihove ugotovitve so podprle predpostavke RAM, da okoljski dražljaji (dodatno zdravljenje raka in resnost bolezni) vplivajo na bio-psiho-socialne odzive.

Bolečina pri raku se lahko pojavi na kateri koli stopnji bolezni: ob postavitvi diagnoze (kot simptom), med in po zdravljenju, v napredovali, vendar stabilni bolezni in $\mathrm{v}$ terminalni fazi (Chapman, 2012). Bolečina je med najpogostejšimi simptomi, ki se pojavijo pri pacientih z napredovalim rakom (Kumar, 2011). Breivik in sodelavci (2009) ugotavljajo, da bolečina vpliva na vsakodnevne dejavnosti in socialne stike. Bolečina zdaj na splošno velja kot peti vitalni znak, ki bi moral biti del rednega ocenjevanja pacienta. Znanje, veščine in ustrezna orodja za ocenjevanje bolečine niso nič manj pomembni od tistih, ki veljajo za ocenjevanje ostalih vitalnih znakov (Ashbaugh, 2005). Spoprijemanje predstavlja del odstopanja prilagoditve na kronično bolečino (Richardson \& Poole, 2001). Kadar imamo opravka s kronično bolečino, ki jo povzroča rak, je zelo pomembno, da se s pacientom pogovorimo o naravi njegove bolezni. Medicinska sestra mora spodbujati in 
podpreti pacienta, da svojo bolečino izrazi (Blomberg, et al., 2008). Pacientu je treba razložiti, da je bolečina odraz njegove bolezni. Sodelovanje med pacientom, svojci in zdravstvenim osebjem je pri zdravljenju nujno potrebno. Edino tako je mogoče doseči cilj. Naš cilj je, da bi pacient znal uravnavati bolečino, saj je dejstvo, da kronična bolečina nikoli povsem ne izgine. Če pacienta seznanimo z vzroki bolečine, če ve, zakaj se bolečina pojavi, in če jo zna ublažiti z različnimi zdravili, to lahko pozitivno vpliva na pacientovo kakovost življenja. Naše intervencije so bile usmerjene $\mathrm{v}$ učenje in spodbujanje prilagajanja na način življenja $\mathrm{z}$ bolečino. Pacienti se morajo največkrat odločati $\mathrm{v}$ izrednih razmerah, ko je slabša telesna in spremenjena psihološka zmogljivost ter prisotna socialna izoliranost (Fenwick, et al., 2012). Ne glede na vzrok za nastanek kronične bolečine se pacient sooča $\mathrm{z}$ dihotomno izkušnjo, navajata Richardson in Poole (2001). Po eni strani ga kronična bolečina prisili, da počiva, in $\mathrm{s}$ tem zaščiti prizadeto območje, po drugi strani pa dolgotrajnost kronične bolečine pomeni izključenost iz vsakodnevnih aktivnosti.

Teoretičnih modelov zdravstvene nege je veliko, mi smo se odločili za RAM zaradi predhodnih znanstvenih raziskav s področja bolečine in področja rakavih obolenj. Ali bi model moral biti predhodno testiran in ali lahko sploh model empirično dokazujemo, se sprašuje Tierney (1998), kajti za empirično testiranje so priporočljive teorije zdravstvene nege. Tudi tukaj srečamo neenotnost, ali je Roy zapisala adaptacijski teoretični model ali teorijo. Avtorica v svojem prispevku (Dudley-Brown, 1997) zagovarja vrednotenje tako modelov (priporoča uporabo kriterijev po Fawcett) kot teorij, kjer priporoča branje Meleis. Eni avtorji zagovarjajo, da gre pri adaptacijskem modelu bolj za teorijo, drugi spet za model. Tudi avtorica sama v intervjuju s Fawcett (2009) in Roy (2002) poudari, da se je njen model spreminjal čez čas, zaradi raziskav kot tudi njenega osebnega razvoja in spreminjanja vrednot in spoznanj. Še vedno je aktualen, ker je prepoznaven $\mathrm{v}$ praksi in ker ima vpliv tako na izobraževanje, raziskovanje kot razvoj zdravstvene nege. Zavedamo se omejitve in slabosti raziskave, da gre le za primer, ki ga ne moremo posploševati. Za obravnavo $\mathrm{v}$ praksi je potrebno dobro poznavanje modela. V Sloveniji je tega znanja malo ali pa je nepriljubljeno. Zato bi priporočili v prihodnje več tovrstnega izobraževanja. Frederickson (2011) se sprašuje, kaj pomeni za profesijo zdravstvene nege in izboljšanje prakse zdravstvene nege, če se pri raziskovanju $\mathrm{v}$ zdravstveni negi teoretični modeli ne uporabljajo.

\section{Zaključek}

RAM se je že uporabljal pri obravnavi bolečine in ima dobra teoretična izhodišča, ki so lahko vodilo medicinskim sestram oziroma aktivnostim zdravstvene nege. $\mathrm{V}$ prispevku smo želeli prikazati uporabnost RAM pri pacientu $\mathrm{z}$ rakom, ki ima kronično bolečino. Cilj zdravstvene nege in teoretičnega modela je človekova prilagoditev na štirih prilagoditvenih ravneh v primeru zdravja in bolezni. Ko posameznik ne zmore več prilagoditve na spremembe iz okolja samostojno, potrebuje pomoč, ki mu jo kakovostno lahko zagotovi medicinska sestra, vendar le, če pozna njegove potrebe po prilagajanju. $\mathrm{V}$ prispevku smo s pomočjo scenarija prikazali eno izmed pogostih situacij, ki jo srečujemo pri vsakdanjem delu. Pri procesu reševanja problemov smo pacienta obravnavali v šestih korakih ter ocenili njegovo stanje. S tem smo ugotovili pacientovo vedenje in ocenili dražljaje, ki vplivajo nanj iz okolja, ter na kateri od štirih ravni je prilagajanje moteno. Po določitvi negovalnih diagnoz smo načrtovali cilje, izvedli intervencije ter na koncu ocenili, ali so bili prilagoditveni cilji doseženi. Spoznali smo, da je kljub kompleksnosti RAM v našem primeru uporaben, saj je ključni pojem za RAM ravno pri oceni vedenja pacientov $\mathrm{v}$ procesu ocenjevanja bolečine in vpliva bolečine skozi štiri prilagoditvene ravni. Pacient se bo prilagodil na štirih prilagoditvenih ravneh in s tem smo vplivali na kakovost življenja, fizične aktivnosti in socialno soodvisnost.

Nujno je, da pri svojem delu uporabljamo holistični pristop in zdravstveno nego načrtujemo individualno. Pomembno je zavedanje, da lahko medicinska sestra s psihosocialno podporo vpliva na kakovost življenja $\mathrm{v}$ času bolezni in ohranja zdravje pacienta. Pri pregledu literature lahko vidimo, da je RAM globoko zasidran v praksi zdravstvene nege, kar v določeni meri prispeva $\mathrm{k}$ njegovemu neprekinjenemu uspehu. Ostaja eden najpogosteje uporabljenih konceptualnih okvirov za poučevanje zdravstvene nege. Prilagoditveni model Calliste Roy daje koristno ogrodje delu medicinske sestre in raznolike informacije o posameznikovem prilagajanju na dražljaje in dejavnike iz okolja.

\section{Literatura}

Abu Shosha, G. \& Al Kalaldeh, M.A., 2012. A critical analysis of using Roy's adaptation model in nursing research. International Journal of Academic Research, 4(4), pp. 26-31. http://dx.doi.org/10.7813/2075-4124.2012/4-4/B.3

Ashbaugh, C.M., 2005. Assessing acute pain in the geriatric population: a master project submitted to the faculty of the college of nursing. Arizona: The University of Arizona, pp. 10-43.

Bakan, G. \& Akyol, A.D., 2008. Theory-guided interventions for adaptation to heart failure. Journal of Advanced Nursing, 61(6), pp. 596-608.

http://dx.doi.org/10.1111/j.1365-2648.2007.04489.x

PMid:18302601

Baldacchino, D., Torskenaes, K., Kalfoss, M., Borg, J., Tonna, A., Debattista, C., et al., 2013. Spiritual coping in rehabilitation - a comparative study: part 1. The British Journal of Nursing, 22(4), pp. 228-232.

PMid:23448986 
Blomberg, A.M., Hylander, I. \& Törnkvist, L., 2008. District nurses' involvement in pain care: a theoretical model. Journal of Clinical Nursing, 17(15), pp. 2022-2031.

http://dx.doi.org/10.1111/j.1365-2702.2007.02222.x

PMid:18720560

Breivik, H., Cherny, N., Collett, B., de Conno, F., Filbet, M., Foubert, A.J. et al., 2009. Cancer-related pain: a pan-European survey of prevalence, treatment, and patient attitudes. Annals of Oncology, 20(8), pp. 1420-1433.

http://dx.doi.org/10.1093/annonc/mdp001

PMid:19244085

Brower, H.T. \& Baker, B.J., 1976. The Roy adaptation model. Using the adaptation model in a practitioner curriculum. Nursing Outlook, 24(11), pp. 686-689.

PMid:1049428

Büssing, A., Ostermann, T., Neugebauer, E.A. \& Heusser, P., 2010. Adaptive coping strategies in patients with chronic pain conditions and their interpretation of disease. BioMed Central Public Health. 20;10, p. 507.

http://dx.doi.org/10.1186/1471-2458-10-507

PMid:20727191; PMCid:PMC2936426

Chapman, S., 2012. Cancer pain part 2: assessment and management. Nursing Standard, 26(48), pp. 44-49.

http://dx.doi.org/10.7748/ns2012.08.26.48.44.c9229

PMid:22916657

Dobratz, M.C., 2005. A comparative study of life-closing spirituality in home hospice patients. Research and Theory for Nursing Practice, 19(3), pp. 243-256.

http://dx.doi.org/10.1891/rtnp.2005.19.3.243

PMid:16144242

Dudley-Brown, S.L., 1997. The evaluation of nursing theory: a method for our madness. International Journal of Nursing Studies, 34(1), pp. 76-83.

http://dx.doi.org/10.1016/S0020-7489(96)00024-7

PMid:9055124

Fawcett, J., 2005. Criteria for evaluation of theory. Nursing Science Quarterly, 18(2), pp. 131-135.

http://dx.doi.org/10.1177/0894318405274823

PMid:15802745

Fawcett, J., 2009. Using the Roy adaptation model to guide research and/or practice: construction of conceptualtheoretical-empirical systems of knowledge. Aquichan, 9(3), pp. 297-306.

Fenwick, C., Chaboyer, W. \& St John, W., 2012. Decisionmaking processes for the self-management of persistent pain: a grounded theory study. Contemporary Nurse, 42(1), pp. 53-66. http://dx.doi.org/10.5172/conu.2012.42.1.53

PMid:23050572
Frederickson, K., 2011. Callista Roy's adaptation model. Nursing Science Quarterly, 24(4), pp. 301-303.

http://dx.doi.org/10.1177/0894318411419215

PMid:21975474

Hajdinjak, G. \& Meglič, R., 2012. Sodobna zdravstvena nega. 2. dopolnjena izd. Ljubljana: Univerza v Ljubljani, Zdravstvena fakulteta, pp. 266-290.

Kumar, S.P., 2011. Utilization of brief pain inventory as an assessment tool for pain in patients with cancer: a focused review. Indian Journal of Palliative Care, 17(2), pp. 108-115. http://dx.doi.org/10.4103/0973-1075.84531

PMid:21976850; PMCid:PMC3183599

Marriner-Tomey, A. \& Raile Alligood, M., 2006. Nursing theorists and their work. $6^{\text {th }}$ ed. St. Louis: Mosby/Eelsevier, pp. 359-385.

Masters, K., 2012. Nursing theories: a framework for professional practice. Sudbury: Jones \& Bartlett, p. 137.

Maxwell, T., Givant, E. \& Kowalski, M.O., 2001. Exploring the management of bone metastasis according to the Roy Adaptation Model. Oncology Nursing Forum, 28(7), pp. 1173-1181.

PMid:11517850

McCurry, M.K., Revell, S.M. \& Roy, S.C., 2010. Knowledge for the good of the individual and society: linking philosophy, disciplinary goals, theory, and practice. Nursing philosophy, 11(1), pp. 42-52.

http://dx.doi.org/10.1111/j.1466-769X.2009.00423.x

PMid:20017882

Meleis, A.I., 2007. Theoretical nursing: development and progress. 4th edn. Philadelphia: Lippincott Williams \& Wilkins, pp. 291-307.

Nicholson, N.R. Jr., 2009. Social isolation in older adults: an evolutionary concept analysis. Journal of Advanced Nursing, 65(6), pp. 1342-1352.

http://dx.doi.org/10.1111/j.1365-2648.2008.04959.x PMid:19291185

Nuamah, I.F., Cooley, M.E., Fawcett, J. \& McCorkle, R., 1999. Testing a theory for health-related quality of life in cancer patients: a structural equation approach. Research in Nursing \& Health, 22(3), pp. 231-242.

http://dx.doi.org/10.1002/(S I C I) 1098 240X(199906)22:3<231::AID-NUR5>3.0.CO;2-6

PMid:10344703

Parker, M.E. ed., 2006. Nursing theories and nursing practice. 2nd edn. Philadelphia : F. A. Davis, pp. 268-280.

Phillips, K.D., 2011. Conceptual development of an instrument to measure the internalized stigma of AIDS based on the Roy adaptation model. Nursing Science Quarterly, 24(4), pp. 306-310.

http://dx.doi.org/10.1177/0894318411419222

PMid:21975476 
Pinquart, M. \& Frohlich, C., 2009. Psychosocial resources and subjective well-being of cancer patients. Psychology \& Health, 24(4), pp. 407-421.

http://dx.doi.org/10.1080/08870440701717009

PMid:20205002

Raile Alligood, M., 2011. The power of theoretical knowledge. Nursing Science Quarterly, 24(4), pp. 304-305.

http://dx.doi.org/10.1177/0894318411419221

PMid:21975475

Ramini, S.K., Brown, R. \& Buckner, E.B., 2008. Embracing changes: adaptation by adolescents with cancer. Pediatric Nursing. 34(1), pp. 72-79.

PMid:18361091

Ramšak Pajk, J., 2013. Aktivnosti zdravstvene nege med teorijo in prakso. In: Pivač, S., Kalender Smajlović, S., Černoga, A., Skinder Savič, K., Hvalič Touzery, S., Skela Savič, B. eds. Izbrane intervencije zdravstvene nege - teoretične in praktične osnove za visokošolski študij zdravstvene nege: visokošolski učbenik za zdravstveno nego. Jesenice: Visoka šola za zdravstveno nego, pp. 12-22.

Reed, P.G., 1995. A treatise on nursing knowledge development for the 21st century: beyond postmodernism. Advances in Nursing Science, 17(3), pp. 70-84.

http://dx.doi.org/10.1097/00012272-199503000-00008

PMid:7778892

Richardson, C. \& Poole, H., 2001. Chronic pain and coping: a proposed role for nurses and nursing models. Journal of Advanced Nursing, 34(5), pp. 659-667.

http://dx.doi.org/10.1046/j.1365-2648.2001.01795.x

PMid:11380734

Rogers, C. \& Keller, C., 2009. Roy's adaptation model to promote physical activity among sedentary older adults. Geriatric nursing, 30(2 Suppl), pp. 21-6.

http://dx.doi.org/10.1016/j.gerinurse.2009.02.002

PMid:19345860; PMCid:PMC2855388

Roy, C. \& Andrews, H., 1999. The Roy adaptation model. 2nd ed. Stamford: Appleton \& Lange, pp. 14-86.

Roy, C., 1970. Adaptation: a conceptual framework for nursing. Nursing Outlook, 18(3), pp. 42-45.

PMid:5197607

Roy, C., 1971. Adaptation: a basis for nursing practice. Nursing Outlook, 19(4), pp. 254-257.

PMid:5205575
Roy, C., 1997. Future of the Roy model: challenge to redefine adaptation. Nursing Science Quarterly, 10(1), pp. 42-48.

http://dx.doi.org/10.1177/089431849701000113

PMid:9277177

Roy, C., 2002. The nurse theorists: 21st-century updatesCallista Roy. Interview by Jacqueline Fawcett. Nursing Science Quarterly, 15(4), pp. 308-310.

PMid:12387228

Roy, C., 2011. Research based on the Roy adaptation model: last 25 years. Nursing Science Quarterly, 24(4), pp. 312-320.

http://dx.doi.org/10.1177/0894318411419218 PMid:21975478

Schluter, J., Seaton, P. \& Chaboyer, W., 2008. Critical incident technique: a user's guide for nurse researchers. Journal of Advanced Nursing, 61(1), pp. 107-114

http://dx.doi.org/10.1111/j.1365-2648.2007.04490.x

PMid:18173737

Skjutar, Å. \& Müllersdorf, M., 2010. Adapt, discover and engage: a qualitative interview study with patients living with chronic pain. Journal of Nursing and Healthcare of Chronic Illness, 4(2), pp. 254-261.

http://dx.doi.org/10.1111/j.1752-9824.2010.01066.x

Snoj, Z., 2009. Psihološka priprava bolnikov z rakom. Farmacevtski Vestnik, 60(2), pp. 77-79. Available at: http://www. dlib.si/?URN=URN:NBN:SI:DOC-LEHWVUKO [20. 11. 2013].

Tierney, A.J., 1998. Nursing models: extant or extinct? Journal of Advanced Nursing, 28(1), pp. 77-85.

http://dx.doi.org/10.1046/j.1365-2648.1998.00766.x

PMid:9687133

Tsai, P.F., Tak, S., Moore, C. \& Palencia, I., 2003. Testing a theory of chronic pain. Journal of Advanced Nursing, 43(2), pp. $158-169$.

http://dx.doi.org/10.1046/j.1365-2648.2003.02690.x PMid:12834374

Weinert, C., Cudney, S. \& Spring, A., 2008. Evolution of a conceptual model for adaptation to chronic illness. Journal of nursing scholarship, 40(4), pp. 364-372.

http://dx.doi.org/10.1111/j.1547-5069.2008.00241.x

PMid:19094152; PMCid:PMC2765108

Yeh, C.H., 2002. Health-related quality of life in pediatric patients with cancer: a structural equation approach with the Roy Adaptation Model. Cancer Nursing, 25(1), pp. 74-80. http://dx.doi.org/10.1097/00002820-200202000-00013

PMid:11838723

Citirajte kot/Cite as:

Čaušević, M., \& Ramšak Pajk, J., 2014. Aplikacija adaptacijskega modela Calliste Roy pri pacientu z rakom in s kronično bolečino. Obzornik zdravstvene nege, 48(1), pp. 40-49. http://dx.doi.org/10.14528/snr.2014.48.1.11 